\title{
ANCIENT SHIPYARD ON TURKEY’S DANA ISLAND: ITS 3D MODELLING WITH PHOTOGRAMMETRY AND COMPUTER GRAPHICS
}

\author{
A. Denker ${ }^{1}$, H. Oniz ${ }^{2}$ \\ ${ }^{1}$ Faculty of Engineering and Natural Sciences, Istanbul Bilgi University, 34060 Eyup, Istanbul, Turkey- ahmet.denker@bilgi.edu.tr \\ ${ }^{2}$ Dept. of Archaeology, Selcuk University, 42130 Secuklu, Konya, Turkey - hakan.oniz@gmail.com
}

\section{Commission II, WG 11/8}

KEY WORDS: Ancient shipyard, 3D Modelling, Photogrammetry, Computer Graphics, Visualization.

\begin{abstract}
:
Although a small island $2 \mathrm{~km}$ off the southern coast of Turkey, Dana Island offers a rich history which is likely to shed light upon the Dark Ages. Starting from 2015 our archaeological team discovered through continuing coastal and underwater excavations 274 shipsheds/slipways there. This discovery places Dana Island among the biggest shipyards of antiquity. The slipways varied in dimensions suitable for vessels of different sizes from small boats to large warships. Historical sources suggest that the name of the island may stem from Yadnana, Yadana or Adana which was mentioned in an Assyrian tablet of the 8th century BC, as an island in the vicinity of Cyprus. Archaeological evidence exists that shows Dana Island had played a significant role in seamanship activities in Levant starting from Neolithic times. A substantial part of the naval campaigns must have involved Dana Island which used be the biggest shipyard/naval base of the Eastern Mediterranean. A 3D model of the island has been made by using photogrammetry and computer graphics methods and simulations were executed to check the hypotheses related to the involvement of Dana Island in the major sea battles of antiquity, such as Sea Battle of Lade in 495 BC.
\end{abstract}

\section{INTRODUCTION}

Since the Dark Ages, warships have formed the backbone of military strength in the Mediterranean. In those days, the sea power was even more important than it is today; it was the way to have military, political, and economic influence. Being strong required having warships. Their construction, storage, repair and maintenance meant a great financial commitment and tremendous economic investment. It was very important that the warships were kept "safe" and "seaworthy" at times they were not used, and that this power was "always ready" and, if necessary, available for use timely and without delay. In a short notice, or even in a sudden situation, these vessels must have been available for rapid launching from their shelters and be ready to sail as soon as they are in water. "Shipsheds" and "slipways" played a vital role in keeping precious vessels safe and close to the sea. These basic maritime structures also played a role of shelter as well as facilitating hauling from and launching into water. Another important role they played was that warships were exhibited as a deterrent force, some of them were built to impress. What is striking is that despite their importance, very few sites have entered the literature as shipsheds or slipways. Ancient "shipsheds" and "slipways" were discovered by our excavation team in Dana Island of Rough Cilicia.

The purpose of this article is to incorporate them in the historical context, starting from archaeological finds, and other material evidence. How these complexes were used in housing the fragile wooden vessels, how functional they were in quickly launching these vessels in suddenly emerging situations are some of the topics upon which we tried to shed light. In order to illuminate the role these structures played as "shipsheds" and "slipways", we modelled the island and its structures by using photogrammetry and 3D computer graphics methods. Simulations have been carried out to verify the hypothesis of the use of this site as a naval base and shipyard starting from the Neolithic times.

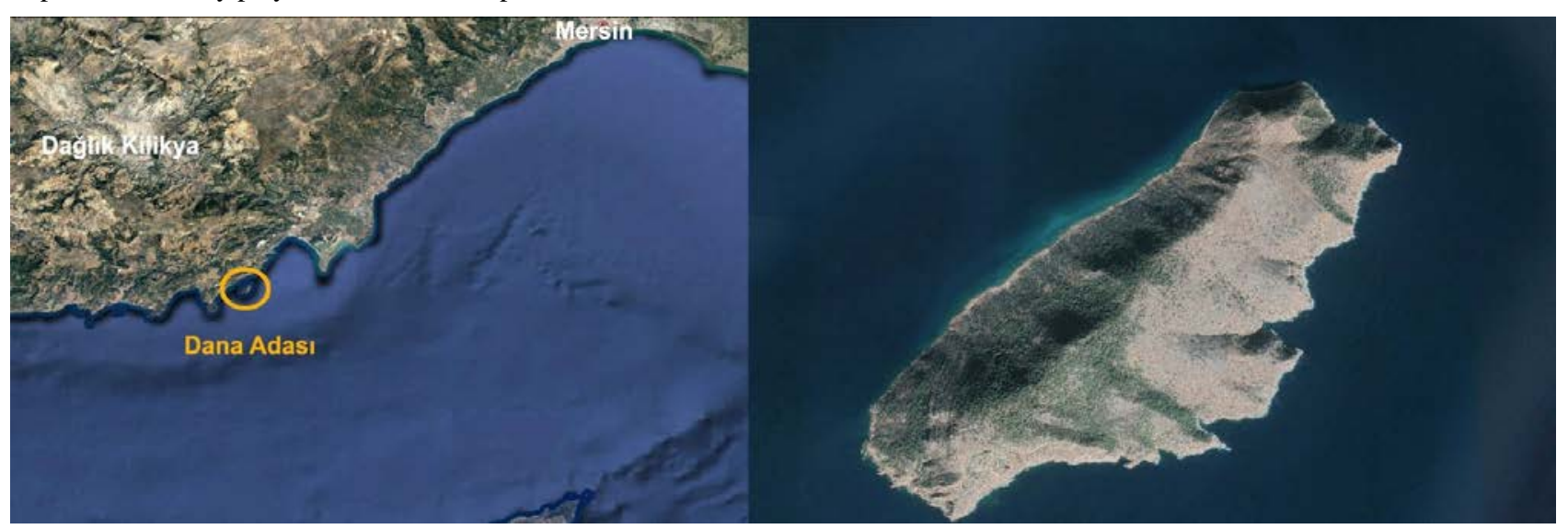

Figure 1. Dana Island is in the east of the Rough Cilicia region on the Mediterranean coast of Turkey 


\section{DANA ISLAND}

Dana Island is a small island in the east of the Rough Cilicia region on the Mediterranean coast of the Anatolian Peninsula, facing the Silifke district of Mersin. It is $2300 \mathrm{~m}$ far from the coast, with a length of $2700 \mathrm{~m}$, a width of $900 \mathrm{~m}$ and a height of $202 \mathrm{~m}$ (Fig. 1). The island is situated between two archaeologically important areas; The first of these is the Tasucu headland which lies between the ancient cities of Holmia and Seleukeia (Silifke); the other is Tisan-Aphrodisias headland at the border of Silifke. Rough Cilicia was also in the scene of regional and interregional political developments as well as intense commercial activities due to strategically important cedar forests for shipbuilding in the Taurus Mountains and iron ore deposits in the Gazipasha and Anamur regions. Since 2015, 274 slipways have been identified in situ, in underwater surveys conducted on the shores of Silifke Dana Island by our excavation team (Oniz, 2017). During the years 2016 and 2017, thanks to both underwater and surface surveys, confirmatory findings were unearthed giving further evidence to that these sites were used as shipsheds and docking sites at different times, starting from the Bronze Age. Slipways' widths vary from 5 to $7 \mathrm{~m}$, and their lengths change from 14 to $20 \mathrm{~m}$. There were multiple reasons for choosing this island as a naval base/shipyard. First, the wood resources needed for shipbuilding were very close to the island.

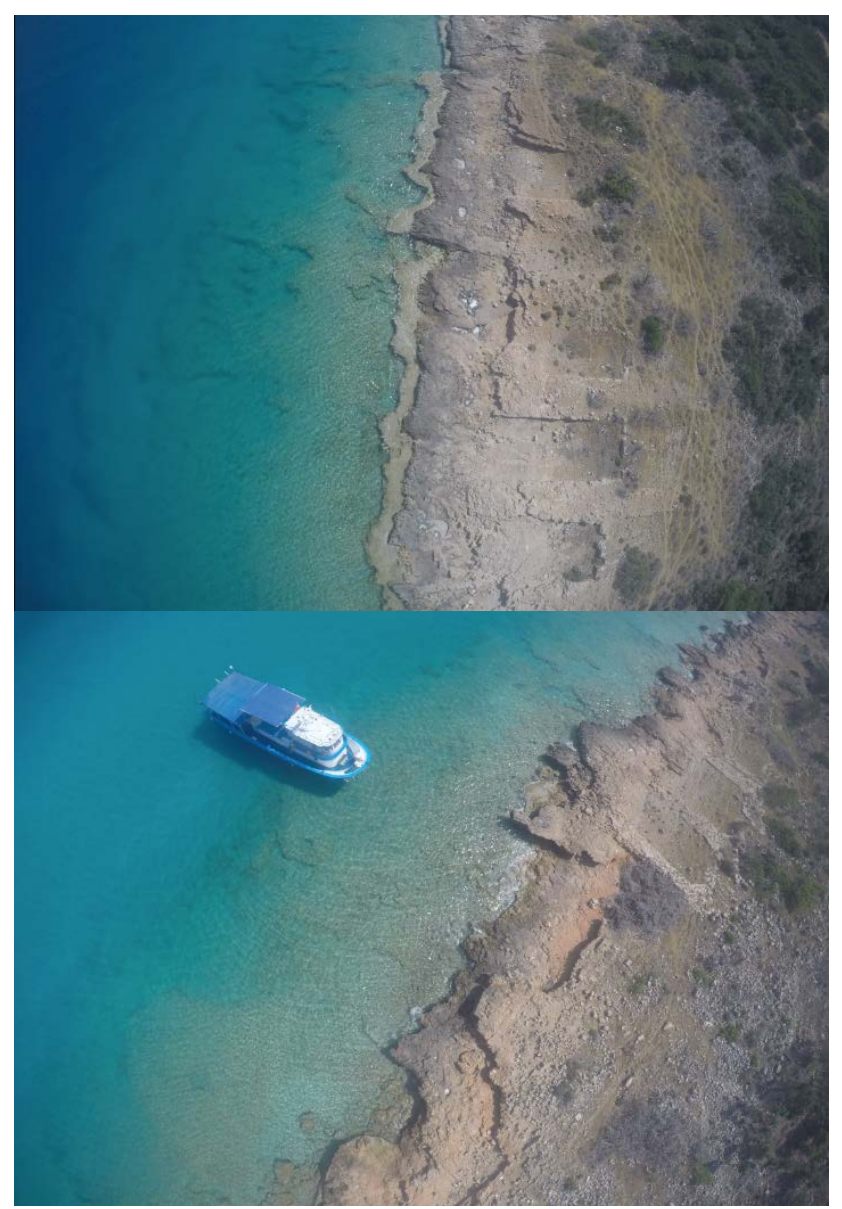

Figure 2. Aerial view of the slipways side by side

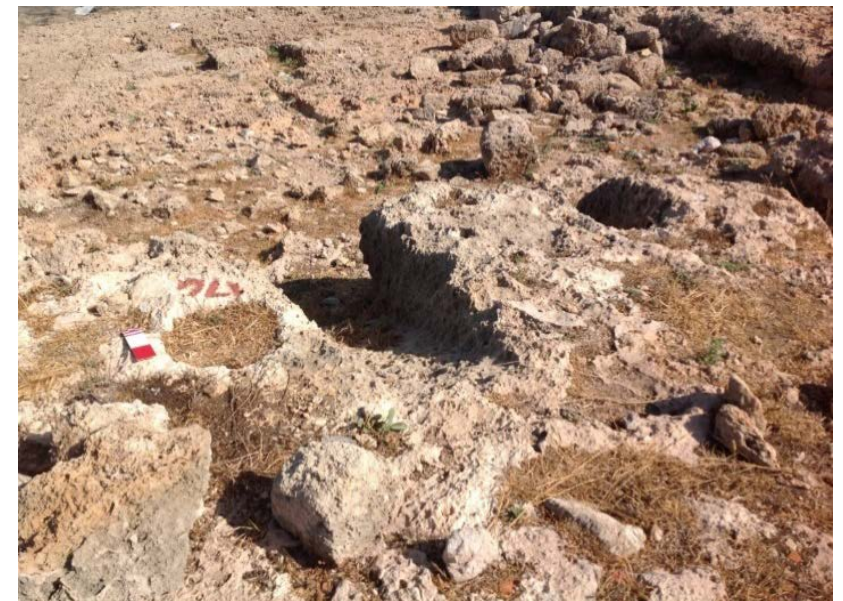

Figure 3. Pole holes suggest that some of the slipways had roofs

It was known that Rough Cilicia was rich in terms of timber resources which are important in shipbuilding. Since the Bronze Age, there are a wealth of tree species such as black pine, red pine, white pine, oak and sandalwood in the region, as well as rich cedar wood resources known to the Taurus Mountains. The second reason for being chosen as a naval base / shipyard is because it is an island, it has provided a safer and easier to protect shelter for the war vessels.

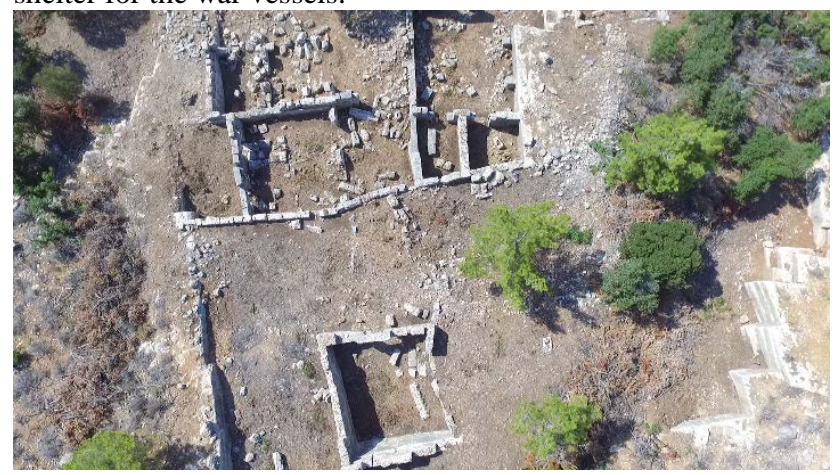

Figure 4. Various building remains were found behind the slipways

"Shipsheds" built on the island should have been more secure than those on the mainland against raids and land attacks.

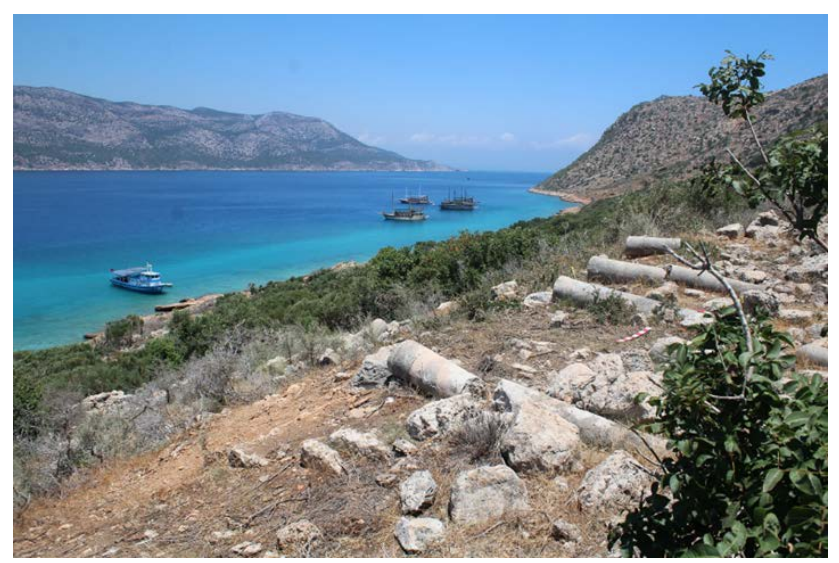

Figure 5. Remnants of a Greek-Roman Temple 


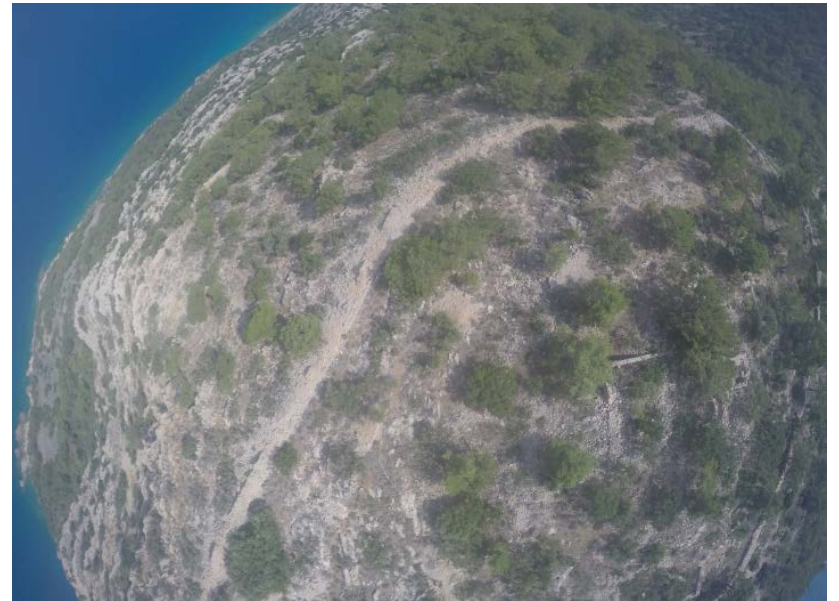

Figure 6. Aerial view of the castle on the highest hill of the island

This hypothesis was reinforced by the presence of a castle remains which showed that the precautions needed to ensure the safety of warships were taken through a specialized headquarters infrastructure and a security wall. Another reason for choosing Dana Island as a naval base / shipyard is that it has a favourable natural troposphere for hauling and launching boats along the north-west coastline. As a matter of fact, all the "slipway" remains on the island are located on the north-west shore where there is a suitable incline to build a ramp from the sea. This incline, which continued uninterrupted along the beach, should have allowed the ships to be pulled in a balanced manner so that their weight would not harm them.

Dana Island's "slipways" are in a rock-cut style, some are supported by stone walls. The pole holes (Fig. 3) in some skirting points suggest that they were used as "ship shelters" and had roofs.

Behind the "slipways", various building remains were found covered with vegetation. They are likely to belong to various workshops/ateliers related to the shipyard. Among the evidences that reinforce this assumption is the presence of numerous melt iron remains in this region. The presence of 274 shipsheds/slipways and the associated workshops/ateliers gives the impression that there was a large naval base and shipyard in the island.

It is understood that in Dana Island, despite there is no arable land and water resources, and despite the fact that the steep slopes of the island are unsuitable for livestock, a significant population had lived. This is deduced from the remnants of villa residences in the island (Fig.4). as well as Roman bath and a Greek / Roman architectural temple (Fig. 5), Over 90 cisterns were identified. These finds explain how water needs were met. Perhaps the most striking is the relatively good condition of the building remains and its surrounding walls at the most commanding location which unquestionably reveals the presence of a fortified castle built at the highest point of the island (Fig. 6). The remnants of this small island support the view that there was a naval base / shipyard from ancient times. The British Admiral Beauforth (Beauforth, 1817: 206-208), who visited the region between 1811 and 1812, was the first who introduced the idea that Dana Island had a possible marine base. In his book Karamania-A Brief Description of the South Coast of Asia Minor, published in 1817, he had reserved a special place for this uninhabited island and had said that there might be an ancient sea base here, based on the fortified wall seen on the hill as well as numerous building remains.

A clue to the possible origin of the name of Dana Island is found in the Assyrian sources. In an Assyrian tablet of the 8th century $\mathrm{BC}$, there exists a mention of an Island in the vicinity of Cyprus which is referred to as Yadnana, Yadana or Adana. (Ünal and Girginer, 2007). At that time, presence of Assyrian assets in the Cilicia region and the existence of a kingdom named Danana are known. It can be considered that Yadana is the Dana Island. However, there is also a need for a more in-depth study of the Assyrian resources in order to say something definite.

\section{PHOTOGRAMMETRIC MODELLING}

Photogrammetry is a century-old method based on mathematics and imaging technology. Over the past century, dramatic progress has been made in methods of obtaining information from photographs about objects. Initially, processes that used to be completely dependent on opto-mechanical devices are increasingly turning into entirely digital workflows.

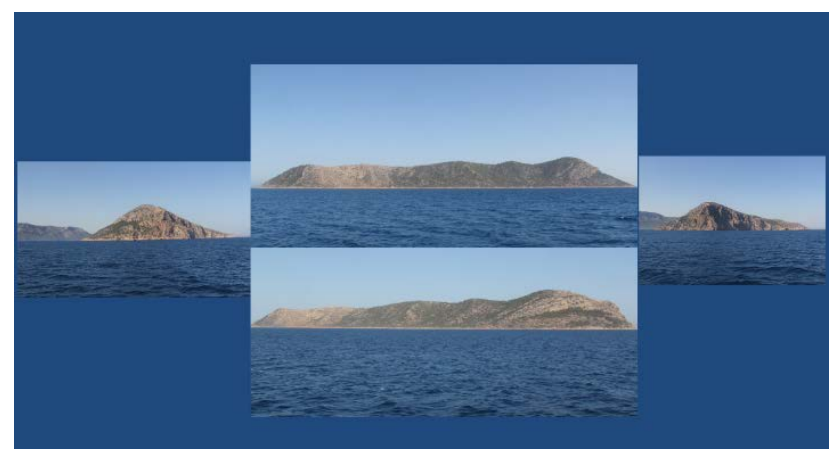

Figure 7. Photographing the island from different angles

Mathematical and technical principles remained the same, but digitization facilitated the widespread use of photogrammetry. For the photogrammetric modelling of the Dana Island, a large number of photographs of the island had to be brought together and the shape, location and colour information obtained therefrom had to be combined. Figure 7 shows four photographs of the island taken from different angles.

In these 2-dimensional photographs, obviously the information about the parts belonging to the 3-dimensional island but not covered in the photos are completely missing. There is no possibility of recovering the missing information about the uncovered parts from the existing pictures without additional computation. However, by taking stereoscopic photographs of the island from slightly different positions consecutively, missing 3D information can be filled in with the help of measurements and calculations. Photographs of a common area are captured from two different vantage points. Effects which reflect $3^{\text {rd }}$ dimension are obtained by processing overlapping images (stereopairs). Information such as rock and surface texture, vegetation and trees in the invisible parts of the island could not be obtained with a handheld camera at a significant distance $(2000 \mathrm{~m})$. Perspective differences stemming from the shape of the island, the position of the camera, the distance, and the objective angle of the camera should also be taken into account. Finally, changes in light conditions affect factors such as brightness and colour distribution. In this case, the photogrammetric modelling method requires measurements to be made besides the acquired images as shown in Figure 8 


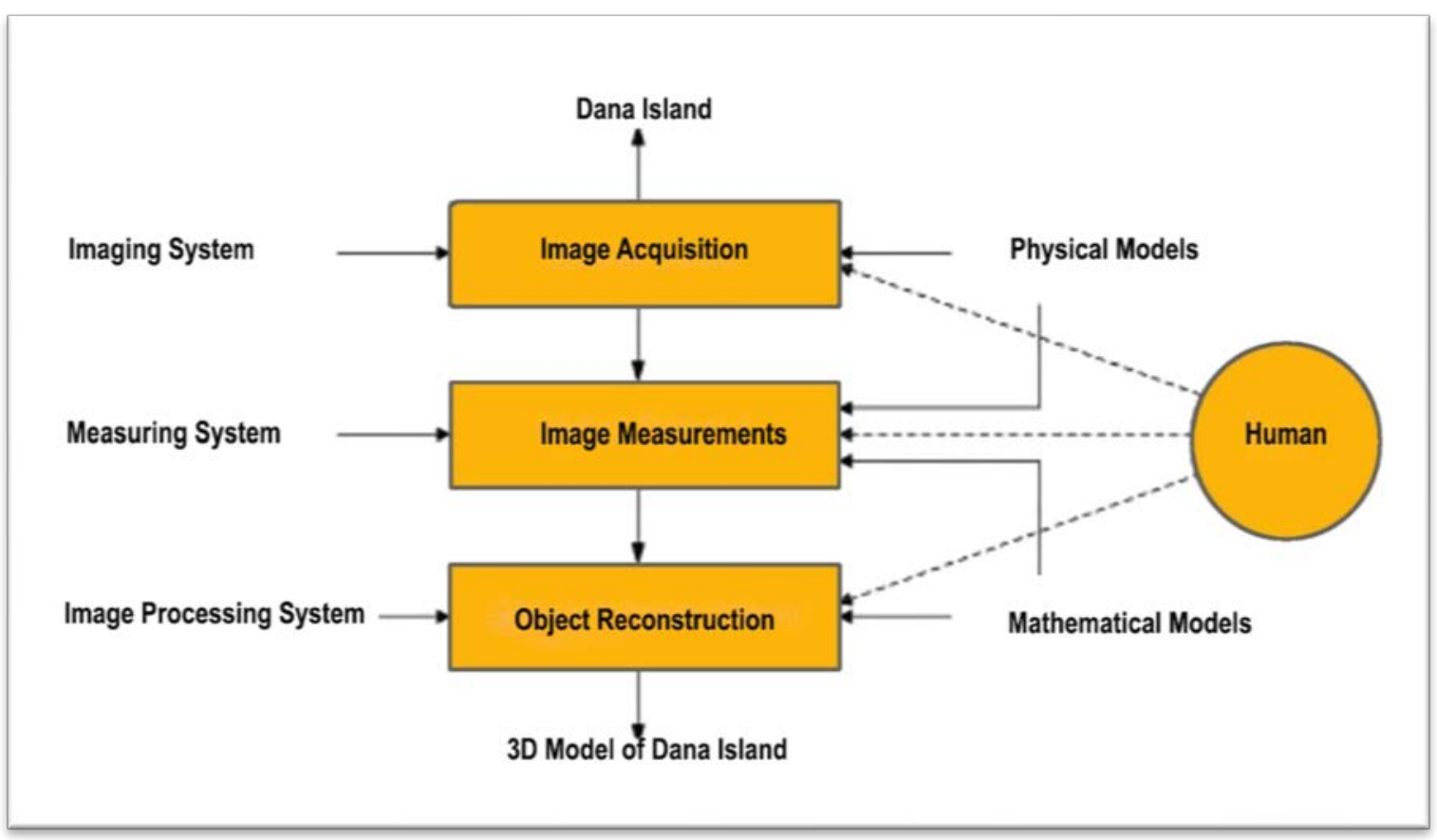

Figure 8. Photogrammetric modelling workflow diagram

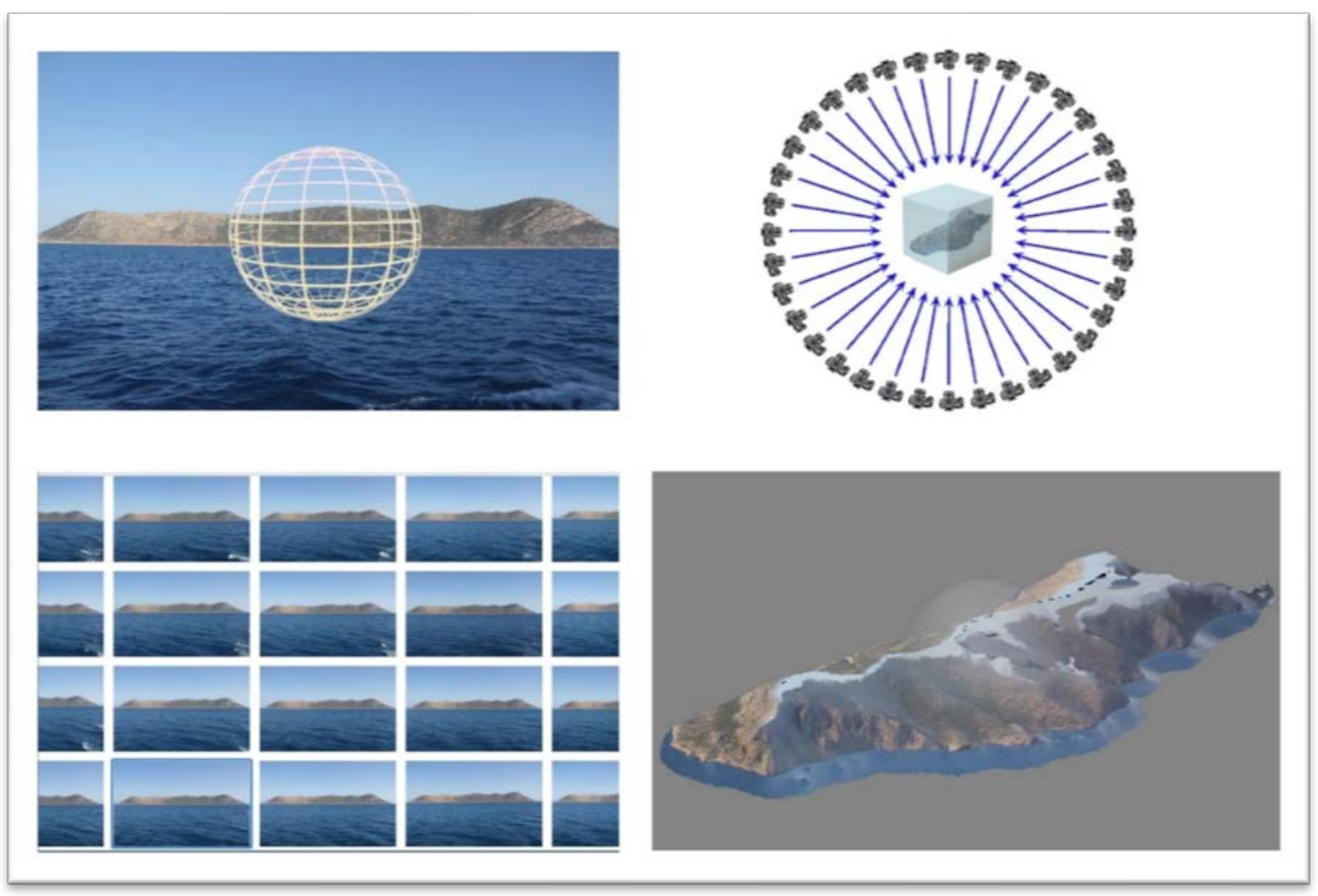

Figure 9. 3D modelling of Dana Island by using photogrammetry 
and the values of light intensity, colour value, exposure angle etc. must be measured and recorded for each image frame. 3D modelling of the island was possible after these measurements and mathematical transformations between the image and the object had been made.

To model the island in a photogrammetric way in 3D, a series of stereoscopic pictures were taken from the deck of a boat encircling the island with 2000 meters (radius), a 35-150 mm lens was used, frames were captured with uniform exposure and the focal length was adjusted continuously to ensure that the viewfinder fills the frame. The images were processed to remove disturbing effects such as reflection of sunlight from the water surface.

The processed images were combined after the coordinate values were set and the merged image was converted to a 3D image using a special purpose software (Fig. 9). For Dana Island photogrammetric modelling has proved to be the ideal data acquisition method for capturing the geometry. Due to sufficient working time a large number of frames were captured, and they provided ample date for 3D reconstruction of the island's geometry. Thus, the first phase was completed to build the model of Dana Island in 3D.

However, for the virtual reconstruction of the island the photogrammetric model was not sufficient on its own. In addition, a literature survey, historical and archaeological analysis were required. They formed the framework for the substantial amount of work for the visualization of the island. Combining photogrammetric model with the computer graphics model in the next section will deliver three types of models: digital terrain and surface models of the island, 3D geometric model and cultural heritage model.

At the end what is aimed is obtaining models which will deliver a realistic perspective walk-through or fly-above the island.

\section{COMPLETION OF THE MODEL WITH COMPUTER GRAPHICS METHODS}

From the aspect of computer graphics, the photogrammetric model is simply a geometric model without thematic information. The methodology adopted here is based on the integration between photogrammetric workflow and the computer graphics methods. The thematic information was added to the 3D geometric model of the island obtained by photogrammetric method by using computer graphic methods such as foliage, rock and surface texture assignment, placement of trees on the island, incorporating the slipways and other places on the island. The steps that are followed using these methods from the geometric object of the island to the realistic appearance are summarized in Fig. 10.

In the modelling of the slipways, firstly 2D drawings were used. These drawings were constructed using the observations made and measurements taken on the island itself, and the different sections of the slipways were reflected (Fig.11). Figure 11a presents a $2 \mathrm{D}$ drawing showing a section from the top of a group of slipways on the coastal side of the island, facing Mersin Silifke. In Figure 11b, a side sectional view is presented showing the positional relationship between the slipways and the workshop/atelier structures above them as well as the typical slope of this section of the island. Using this information, the visualization in Figure 11c is obtained. A special purpose 3D software was used in the transition to 3D. In Fig. 12, the slipway/shipshed areas visualized. They were obtained by cutting the rocks instead of digging the soil depending on the geological substratum on the shore facing the north west. The completed model leads to a 3D visualization which consists of models and maps of the historical island and its shipyard covering a large temporal frame of hundreds of years. It also allows a complex characterization of the ancient site as a result of interrelationships between historical heritage and the topographic context.

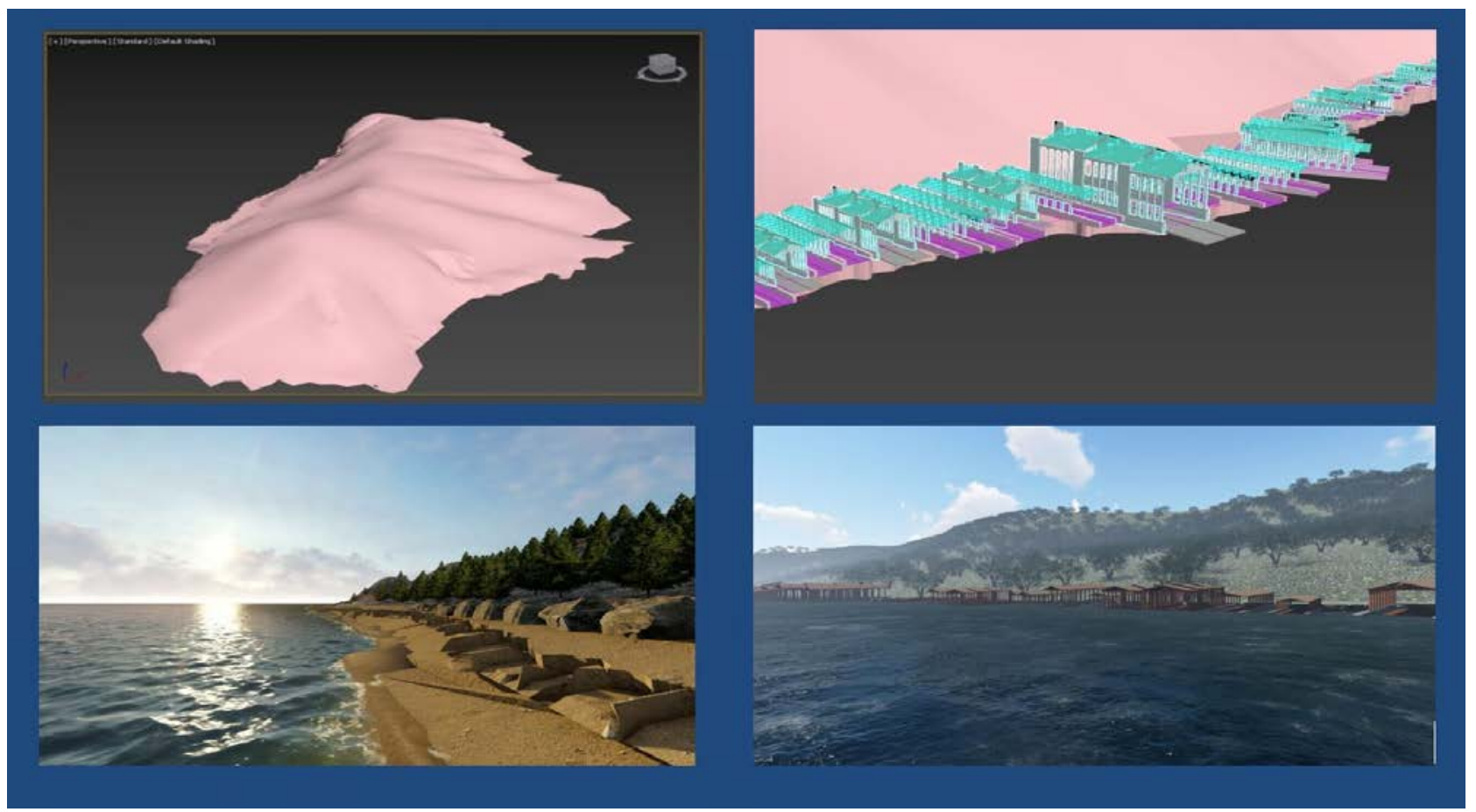

Figure 10 The steps taken from photogrammetric model to 3D visualization 


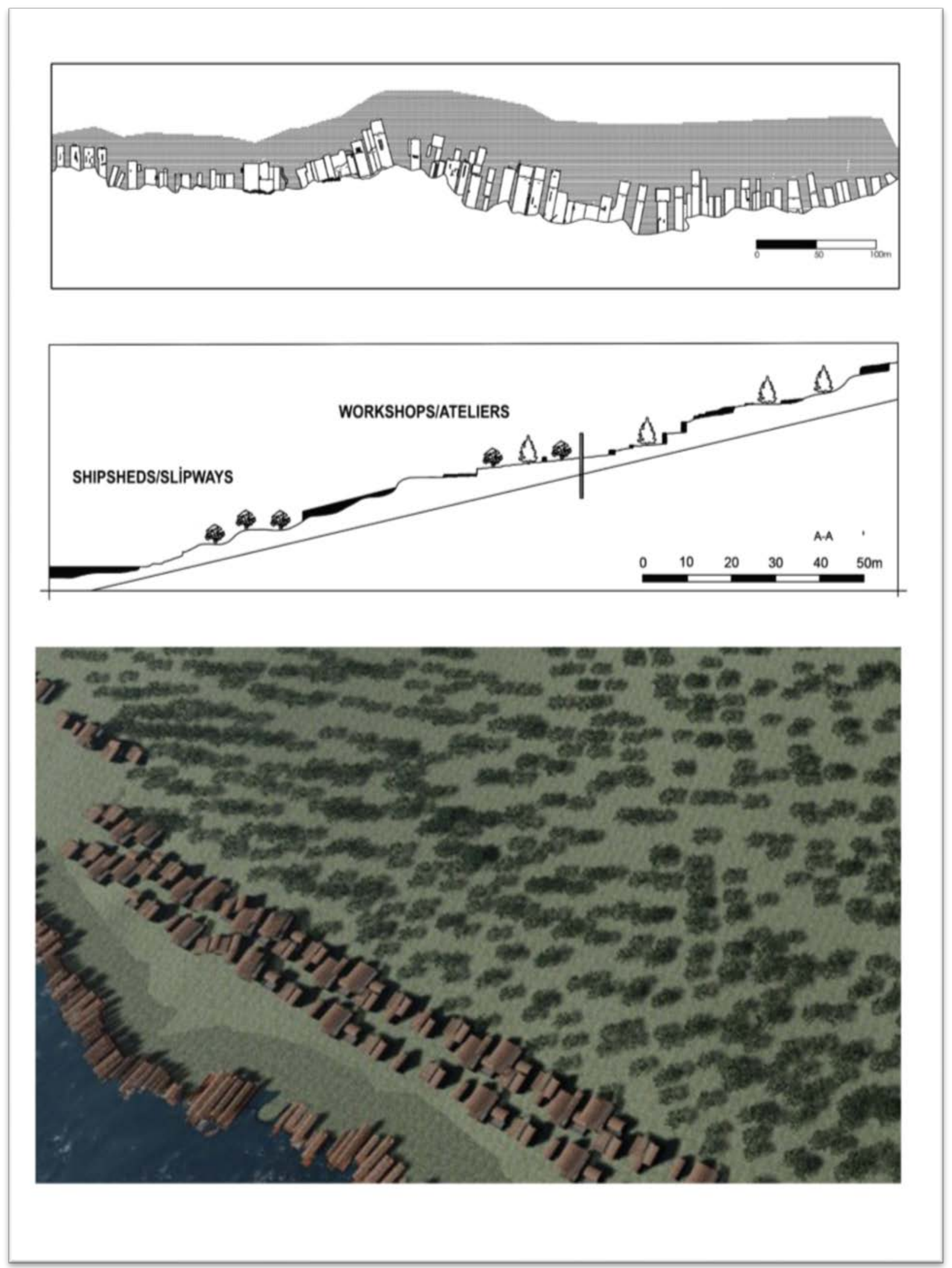

Figure 11 a) 2D drawing showing a section from the top of a group of slipways on the coastal side b) a side sectional view of the positional relationship between the slipways and the workshop/atelier structures c) $3 \mathrm{D}$ visualization 


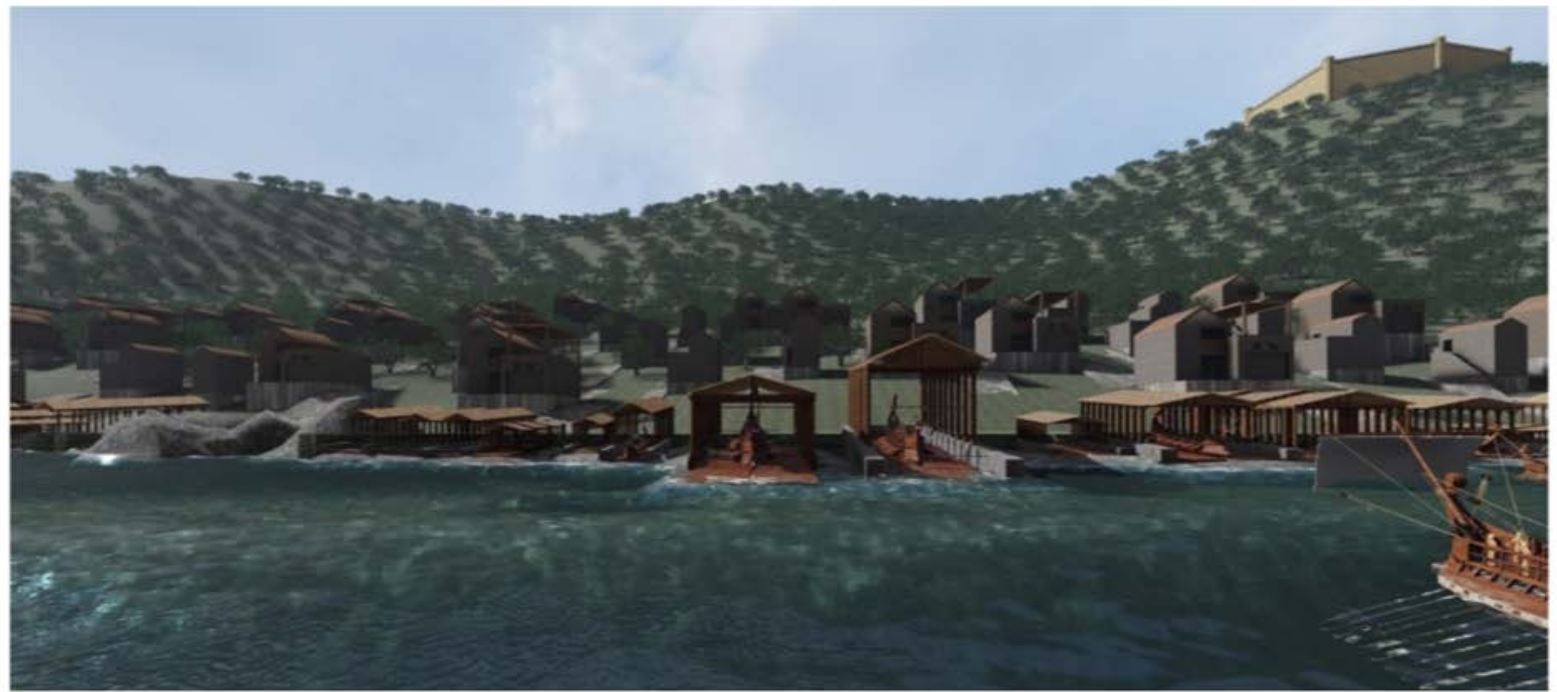

Figure 12 Shipsheds/slipways and workshops/ateliers

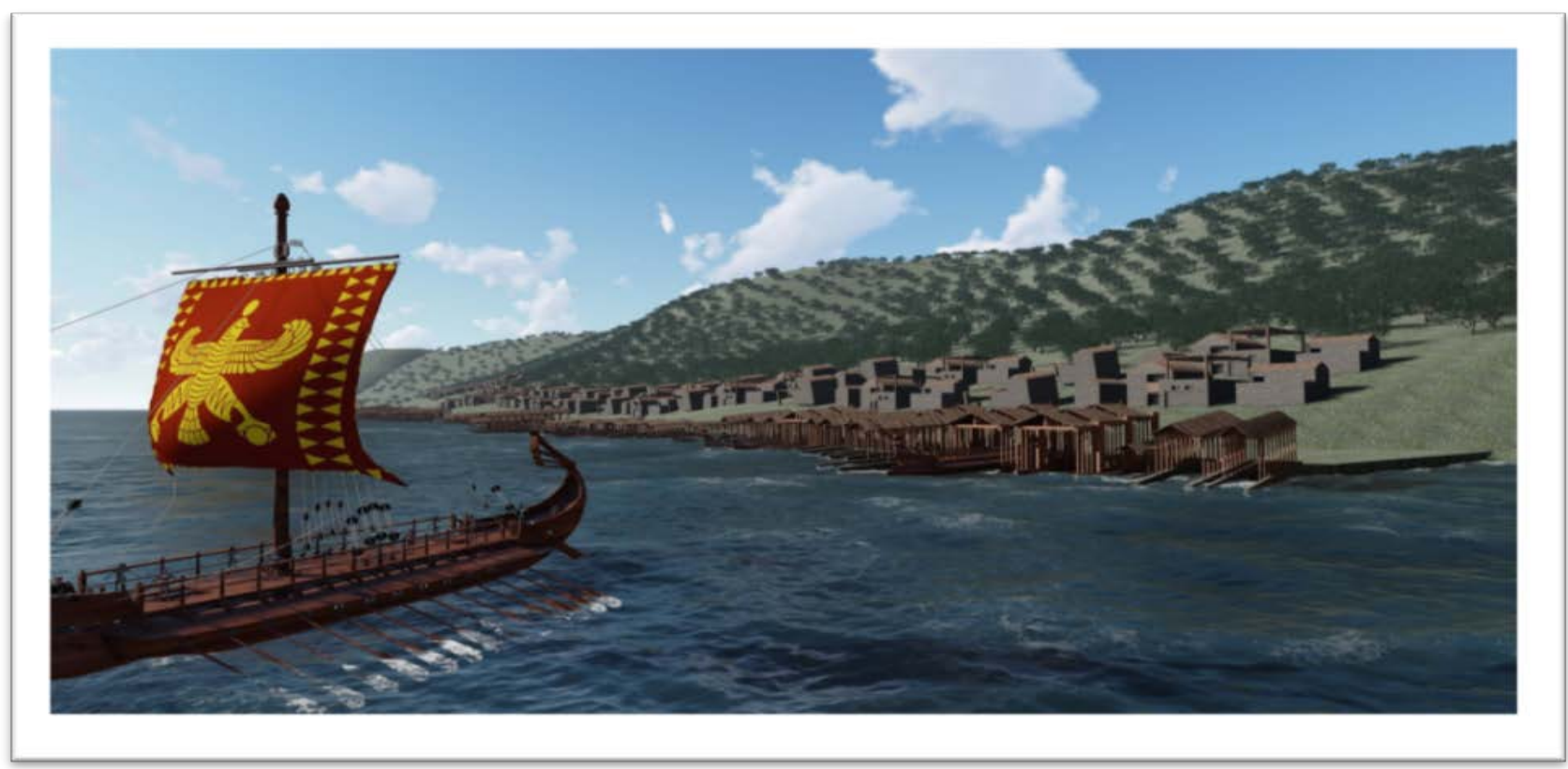

Figure 13 Persian warships during Lade Island naval battle

In Figure 11 slipways were made through cutting rock. The natural slope of the Dana Island simplified the task. During land excavations cutting tools suitable for this type of tasks were unearthed. Apollonius of Rhodes had depicted such landing sites in the Argonautica book, describing how the mythological Argo ship was launched and how it was hauled from the water (Argonautica, 1: 371-7). Homer also described (Homer, II, Book 2, 53), how Achaeans digged slipways on the shores of Troy to haul their warships.

\section{SIMULATIONS AND RESULTS}

With the advent of simulation, it is possible to try many hypotheses and examine their correctness. A further useful aspect of these models is that they allow us to learn more about the ancient warships. Since the war vessels were made of wood, their remains could not survive. The models we created above led us to test whether Dana Island was indeed used as a naval base and to test our hypothesis on it and at the same time make it possible for us to observe what we know about ship architectures of that period. The models presented in Figures 12,13 and14 have been used to simulate the historical facts of a period and have been used visually to understand how Dana Island, located at the geographical centre of many events, might have played a role.

Starting from the middle of the 6th century B.C., The Persians under the rule of Emperor Cyrus II. began to make their power felt in the Eastern Mediterranean. The sea-power of the Persians had been constantly increasing since the beginning of the 5th century, but after the defeat of the Xerxes in 480 BC by the Greeks in the Salamis Naval Battle, their bright era had dimmed (Günaltay, 1951: 13). It is known that Cilician warships constituted part of the Persian Navy. Another historical fact is 


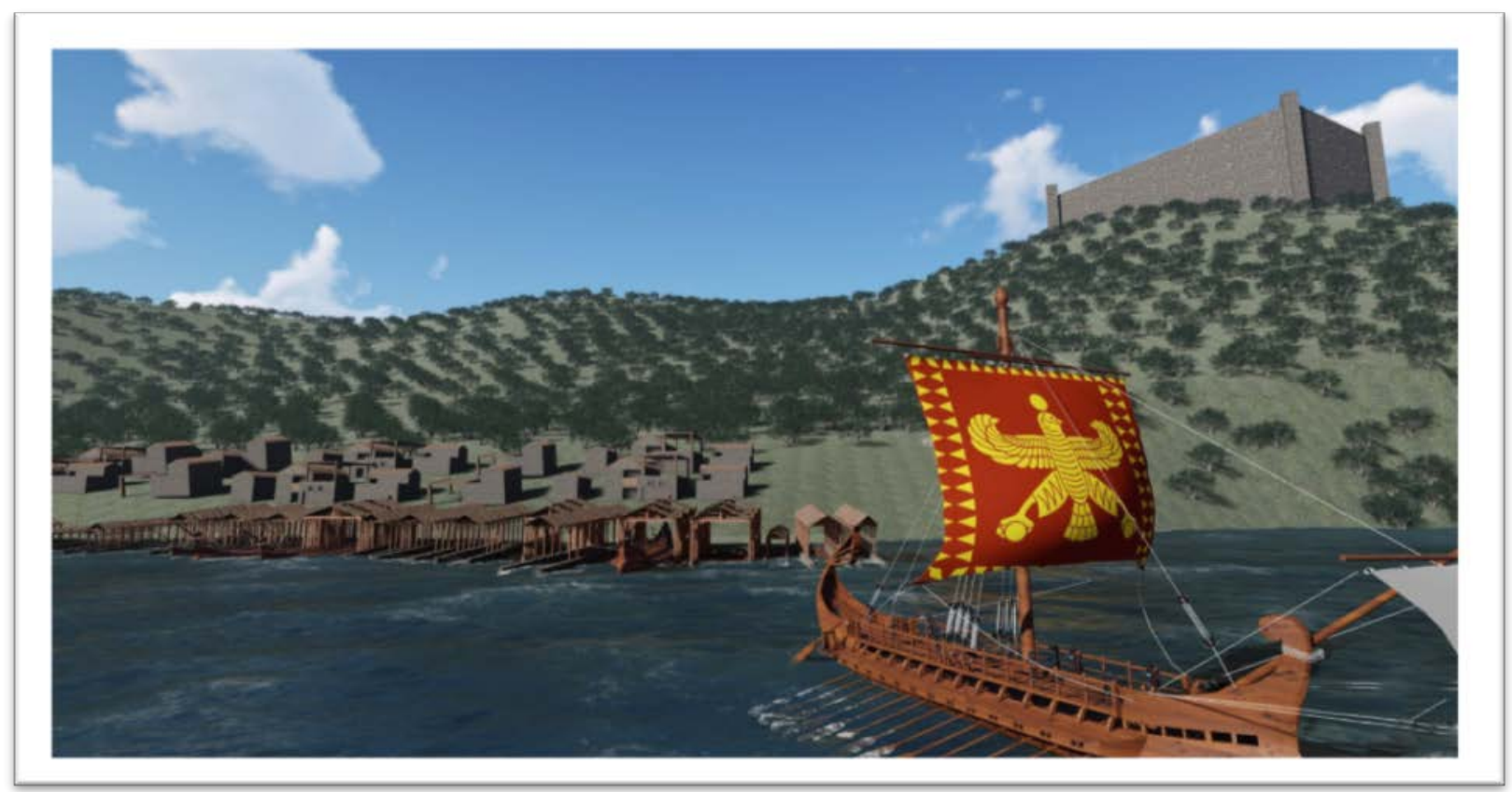

Figure 14 Persian warships during Lade Island naval battle

that the Phoenicians, along with the Persians, participated in the sea wars against the Greeks (Günaltay, 1951: 38). In 494 B.C., under the rule of Emperor Darius, defeated Ionians in the sea battle of Lade Island. Half of the Persian navy were comprised of the ships from Phoenicia, Cilicia and Cyprus. Due to the proximity of Dana Island to these countries, the shipyard / ship base complex found here is conjured to have been used during the sea battle of the Lade Island, suggesting that it also had a brilliant period. The reconstructions in Figures 13 and 14 are presented to revive the island of Dana Island as it was during the Lade Island naval campaigns.

With more than 270 slipway/shipshed remains, Dana Island offers a unique historical richness of ancient times. These animated scenarios that have emerged because of hypotheses today will be refined and reinforced with findings that will be revealed in underwater and surface surveys to be carried out in the coming years. It will be possible to verify the validity of the hypotheses put forth here and to hold a light on the Dark Ages.

\section{ACKNOWLEDGEMENTS}

We thankfully acknowledge our students Günay Dönmez and Dilan Ulusoy from Selcuk University Archaeology Department, who contributed to $2 \mathrm{D}$ drawings and the photographs included in this study, as well as the students of Istanbul Bilgi University Faculty of Engineering and Natural Sciences, Bedrican Orduluoglu, Samet Topçuğlu, M. Soner Yıldırım and Gökhan N. Aydogan for their contributions in 3D modelling.

\section{REFERENCES}

Apollonius, Argonautica I. 371-7

Beauforth, F., 1817. Karamania - A Brief Description of the South Coast of Asia Minor, Printed for R. Hunter, London.

Blackman, D. ve Rankov, B., 2013. Shipsheds of the Ancient Mediterranean, Cambridge University Press, New York.
Blackman, D., 2013. "Classical and Hellenistic Sheds", Shipsheds of the Ancient Mediterranean (Editors: David Blackman and Boris Rankov), Cambridge University Press, New York, 16-29.

Blackman, D., 2013b. "Ramps and Substructures”, Shipsheds of the Ancient Mediterranean (Editors: David Blackman and Boris Rankov), Cambridge University Press, New York, 124-140.

Denker, A., 2018. "Dana Adası ve Deniz Üssü/Tersanesi: 3B Rekonstruksiyonu,” Dana Adası Kollokyumu, 18 Ocak, Mersin.

Günaltay, Ş., 1951. Yakın Şark IV, Perslerden Romalılara Kadar, Türk Tarih Kurumu Yayınları, Ankara.

Homer, History, Book II, 2. 54.

Lider, W., 2016. Digital Photogrammetry: A Practical Course, Springer $4^{\text {th }}$ Ed., ISBN: 978-3362504626.

Öniz, H., 2017. “A Shipyard on Dana Island, Cilicia: Two hundred and seventy-four slipways recently discovered" Sykllis, Zeitschrift für maritime and limnische Archaologie und Kulturgeschichte.

Öniz, H., 2018. "Mersin Kıyıları Sualtı Araștırmaları ve Dana Adası Tersanesi Çalışmaları," Dana Adası Kollokyumu, 18 Ocak, Mersin.

Ünal, A., Girginer. K. S., 2007, Kilikya-Çukurova, İlk Çağlardan Osmanlılar Dönemine Kadar Kilikya 'da Tarihi Coğrafya, Tarih ve Arkeoloji, Homer Kitabevi, Istanbul. 